Article

\title{
An Investigation of the Potential Adoption of Anaerobic Digestion for Energy Production in Irish Farms
}

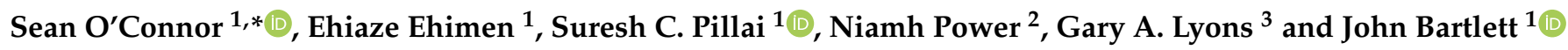 \\ 1 Department of Environmental Science, Institute of Technology Sligo, F91 YW50 Sligo, Ireland; \\ ehimen.ehiaze@itsligo.ie (E.E.); pillai.suresh@itsligo.ie (S.C.P.); bartlett.john@itsligo.ie (J.B.) \\ 2 Sustainable Infrastructure Research and Innovation Research Group, Department of Civil, \\ Structural and Environmental Engineering, Cork Institute of Technology, T12 P928 Cork, Ireland; \\ niamh.power@cit.ie \\ 3 Agri-Environment Branch, Agri-Food and Biosciences Institute, Large Park, Hillsborough BT26 6DR, UK; \\ gary.lyons@afbini.gov.uk \\ * Correspondence: sean.oconnor2@mail.itsligo.ie; Tel.: +353-071-91-55222
}

Citation: O'Connor, S.; Ehimen, E.; Pillai, S.C.; Power, N.; Lyons, G.A.; Bartlett, J. An Investigation of the Potential Adoption of Anaerobic Digestion for Energy Production in Irish Farms. Environments 2021, 8, 8. https://doi.org/10.3390/ environments 8020008

Received: 30 November 2020

Accepted: 20 January 2021

Published: 27 January 2021

Publisher's Note: MDPI stays neutral with regard to jurisdictional claims in published maps and institutional affiliations.

Copyright: (c) 2021 by the authors. Licensee MDPI, Basel, Switzerland. This article is an open access article distributed under the terms and conditions of the Creative Commons Attribution (CC BY) license (https:// creativecommons.org/licenses/by/ $4.0 /)$.

\begin{abstract}
Anaerobic digestion (AD) has been recognised as an effective means of simultaneously producing energy while reducing greenhouse gas (GHG) emissions. Despite having a large agriculture sector, Ireland has experienced little uptake of the technology, ranking 20th within the EU-28. It is, therefore, necessary to understand the general opinions, willingness to adopt, and perceived obstacles of potential adopters of the technology. As likely primary users of this technology, a survey of Irish cattle farmers was conducted to assess the potential of on-farm AD for energy production in Ireland. The study seeks to understand farmers' motivations, perceived barriers, and preferred business model. The study found that approximately $41 \%$ of the 91 respondents were interested in installing $\mathrm{AD}$ on their farming enterprise within the next five years. These Likely Adopters tended to have a higher level of education attainment, and together, currently hold 4379 cattle, potentially providing $37,122 \mathrm{t}_{\text {year }}{ }^{-1}$ of wastes as feedstock, resulting in a potential $\mathrm{CO}_{2}$ reduction of $800.65 \mathrm{t} \mathrm{CO}_{2}$-eq. year ${ }^{-1}$. Moreover, the results indicated that the primary consideration preventing the implementation of $\mathrm{AD}$ is a lack of information regarding the technology and high investment costs. Of the Likely Adopters and Possible Adopters, a self-owned and operated plant was the preferred ownership structure, while $58 \%$ expressed an interest in joining a co-operative scheme. The findings generated provide valuable insights into the willingness of farmers to implement AD and guidance for its potential widespread adoption.
\end{abstract}

Keywords: anaerobic digestion; farm-scale; decentralised; biogas production

\section{Introduction}

To combat the potentially disastrous consequences of climate change, the European Union (EU) has set a goal of reducing its greenhouse gas (GHG) emissions by 80-95\%, relative to 1990 levels by the year 2050 [1]. Crucial legislative milestones in place in order to achieve this goal include the EU 2020 Climate and Energy Package and the EU 2030 Climate and Energy Framework, both of which set binding emission reduction targets for all EU states [2,3]. One country that has struggled to meet its climate change obligations is Ireland, where the country is projected to only reduce their GHG emissions by $2-4 \%$, relative to their $20 \% 2020$ target [4]. A significant factor to this problem is the country's large agriculture sector, which has consistently remained the single largest emitter, producing 33.9\% of total emissions in 2018 [5]. Contributing to this is the country's large livestock population, consisting of 7.21 million cattle and 1.62 million pigs [6]. The dairy sector, in particular, has grown significantly in recent years, where Ireland is now the 10th largest dairy exporter in the world [7]. Much of this growth has stemmed from the removal of the European-wide milk production quotas in 2015. The removal of the quotas saw a rapid growth in the milk 
processed in the country, increasing from 6.2 billion L in 2014 to 8.7 billion L in 2019 [8]. The country currently faces mounting pressure to maintain strong economic growth in its agriculture sector while still meeting emission reduction targets imposed by the EU.

Of the European Union member states, the circumstances surrounding the agriculture sector in Ireland places the country in a unique situation for the potential widespread adoption of anaerobic digestion (AD) technology. Despite the apparent benefits of AD, Ireland has been slow to adopt the technology, ranking 20th in AD deployment among the EU-28 countries [9]. To date, the vast majority of AD installations implemented in Ireland have been for wastewater treatment plants, with only fourteen plants using an agriculture feedstock [10]. Considering that 40 million tonnes of animal manures are produced from Irish livestock annually, the potential for AD adoption is clear [11]. These slurry and manure feedstock streams are theoretically available, but the lack of decentralised AD infrastructure has limited the implementation of the technology to date. [9]. While significant research has been carried out to address technical, political, and environmental concerns related to the development of AD [12-17], relatively little attention has been paid to the motivations and characteristics of the potential adopters of the technology. In comparison, studies addressing this research area internationally are widespread [18-21]. Since Ireland's AD market is still maturing, an increased understanding of the factors influencing the stakeholder adoption process could be particularly beneficial. Furthermore, such information is necessary for policymakers to develop adequate implementation strategies, capable of overcoming obstacles identified and encouraging widespread use. Of the farming types, cattle farmers are particularly promising for the implementation of $\mathrm{AD}$, due to the size of the national herd, the quantity of feedstock available, existing demand for on-site electricity and thermal energy, and the need for emission reduction [12,22].

The focus of this study was to identify Irish cattle farmers' perspectives, motivations and perceived obstacles to the adoption of AD on their farming enterprise and to characterise potential "Likely Adopters" of the technology. The study's findings offer valuable insights into the motivations of likely AD adopters, providing guidance for academics, policymakers, and stakeholders on future implementation strategies.

\section{Materials and Methods}

To address the study's objectives, a survey methodology was utilised. Data collection took place between January 2019 and October 2019. The survey circulated to the participants has been included in the Supplementary Material. The targeted population of the survey were farmers specialising in cattle (beef, dairy, and mixed) in Ireland.

The survey was designed after conducting a detailed literature review and through discussions with academics, farmers and those employed in the agriculture industry. An initial pilot study with several farmers was conducted to finalise the design of the survey. The eventual survey consisted of a cover letter and three pages with twelve questions. These questions were categorised into six sections, each with a specific goal. Section 1 of the survey aimed to collect relevant demographical information, such as the respondent's age, educational attainment, location, farmland, and farming enterprise operation. The second part of the survey sought to assess the respondent's previous interaction with renewable energy (RE) technologies and reasoning (if applicable) for implementation. Section 3 was designed to assess the respondent's likelihood of adopting AD technology on their own farming enterprise. Section 4 focused on understanding the respondent's preferred plant operating conditions if they were to implement the technology. Section 5 used Likert-scale questioning to explore the participant's perception of $\mathrm{AD}$, including the perceived benefits and barriers to its implementation. The final section (section 6) provided an opportunity for respondents to provide any other comments and contact information to receive the results of the study.

Considering the low uptake of farm-scale AD plants in Ireland to date, it was assumed that many of the participants would be unfamiliar with the technology. This assumption was confirmed during the pilot study and initial discussions with farming representatives, 
who were largely unaware of the technology and its features. It was therefore deemed useful to include a brief, unbiased explanation of the AD concept and technology for respondents to give them an introduction to $\mathrm{AD}$, and aid in them answering Section 3 of the survey accurately. Figure 1 presents the explanation and diagram included in the survey to provide the participants with an informed understanding of the technology.

\section{Explanation of Anaerobic Digestion}

- Anaerobic digestion is a renewable energy technology, which can be used on farms to convert manure and energy crops into biogas, which can be then used to produce electricity and heat.

- The benefits include an additional source of revenue, and lowering greenhouse gas emissions.

- An example an anaerobic digestion plant installed in Dendauw in West Flanders (Belgium) had an investment of EUR 95,000. With subsidies the plant achieved a payback period of 7 to 10 years. This farm contained 70 productive dairy cows, 50 heifers, and roughly 100 hens.

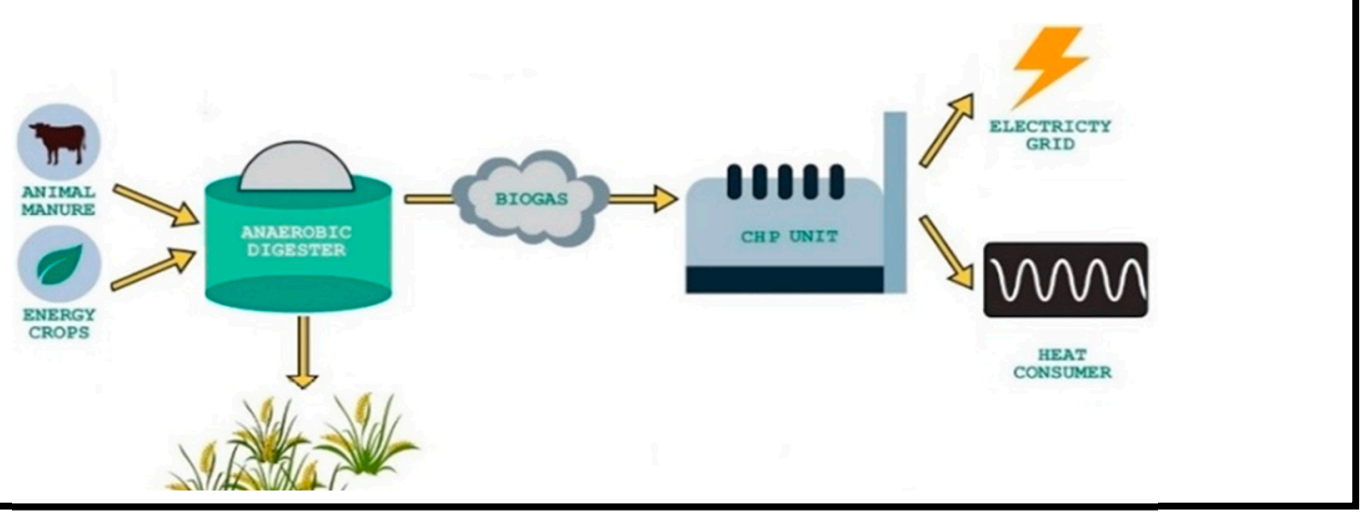

Figure 1. Explanation of AD included in the survey.

The study mainly used two distribution methods to maximise the possible responses. Method A consisted of distributing a paper-based copy of the survey at three large-scale farming-related events; two dairy farm workshops and one industry event. Method $B$ entailed distributing the survey electronically through established mailing lists via a popular service (SurveyMonkey.com).

A total of 95 surveys were returned, of which four responses were deemed as ineligible as they did not engage in cattle farming, leaving 91. Of the eligible responses, 68 were gained through Method A and 23 from Method B. Statistical analyses was carried out using the software packages IBM Statistical Package for the Social Sciences (SPSS) (IBM SPSS Statistics for Windows, v26.0. Armonk, NY, USA: IBM Corp.) and Microsoft Office Excel (Microsoft Office 2016, Microsoft Corporation, Redmond, WA, USA). To identify data trends, statistical techniques were utilised, such descriptive statistics, frequency tables, chi squared tests, and means $t$-tests. In comparison to the national average, the sample of respondents generally had a larger herd and farm size (as shown in Table 1). 
Table 1. Differences in characteristics between Likely Adopters, Possible Adopters, and Non-Adopters.

\begin{tabular}{|c|c|c|c|c|c|}
\hline Characteristics & National Average & All Responses & Likely Adopters & Possible Adopters & Non-Adopters \\
\hline \multicolumn{6}{|l|}{ Livestock (means) } \\
\hline All farms (mean animals) & $66^{\mathrm{a}}$ & 113.7 & 125.1 & 110.3 & 76.1 \\
\hline Dairy farms (mean animals) & $80.0^{b}$ & 118.3 & 120.3 & 118.4 & 113.3 \\
\hline Beef farms (mean animals) & $36.7^{b}$ & 63.3 & 57.3 & 59.2 & 72.1 \\
\hline $\begin{array}{l}\text { Mixed cattle farms (mean } \\
\text { animals) }\end{array}$ & - & 161.9 & 163.9 & 163.3 & 120.0 \\
\hline \multicolumn{6}{|l|}{ Livestock (adopter type \%) } \\
\hline All farms (\%) & - & $100(\mathrm{n}=91)$ & $40.7(n=37)$ & $37.4(n=34)$ & $22.0(n=20)$ \\
\hline Dairy farms (\%) & - & $37.8(\mathrm{n}=34)$ & $40.5(n=15)$ & $32.4(\mathrm{n}=11)$ & $40.0(\mathrm{n}=8)$ \\
\hline Beef farms $(\%)$ & - & $32.2(\mathrm{n}=30)$ & $21.6(\mathrm{n}=8)$ & $35.3(\mathrm{n}=12)$ & $50.0(\mathrm{n}=10)$ \\
\hline Mixed cattle farms (\%) & - & $30.0(\mathrm{n}=27)$ & $37.8(\mathrm{n}=14)$ & $32.4(\mathrm{n}=11)$ & $10.0(\mathrm{n}=2)$ \\
\hline \multicolumn{6}{|l|}{ Farm size (means) } \\
\hline Total area farmed (ha) & $26.49^{a}$ & 62.3 & 56.6 & 64.4 & 69.3 \\
\hline Area owner-occupied (ha) & $22.18^{a}$ & 54.2 & 44.0 & 57.1 & 67.2 \\
\hline Area rented (ha) & $4.31^{\mathrm{a}}$ & 18.2 & 21.6 & 17.7 & 8.4 \\
\hline \multicolumn{6}{|l|}{ Age of respondents (\%) } \\
\hline Less than 35 years (\%) & $5^{a}$ & $15.6(n=14)$ & $27.0(\mathrm{n}=10)$ & $8.8(n=3)$ & $5.3(\mathrm{n}=1)$ \\
\hline $35-44$ years $(\%)$ & $16^{\mathrm{a}}$ & $21.1(\mathrm{n}=19)$ & $16.2(\mathrm{n}=6)$ & $26.5(n=9)$ & $21.1(\mathrm{n}=4)$ \\
\hline $45-54$ years $(\%)$ & $24^{\mathrm{a}}$ & $27.8(\mathrm{n}=25)$ & $27.0(\mathrm{n}=10)$ & $32.4(\mathrm{n}=11)$ & $21.1(\mathrm{n}=4)$ \\
\hline $55-64$ years $(\%)$ & $25^{\mathrm{a}}$ & $28.9(\mathrm{n}=26)$ & $24.3(\mathrm{n}=9)$ & $29.4(\mathrm{n}=10)$ & $36.8(\mathrm{n}=7)$ \\
\hline 65 years and over $(\%)$ & $30^{\mathrm{a}}$ & $6.7(\mathrm{n}=6)$ & $5.4(\mathrm{n}=2)$ & $2.9(\mathrm{n}=1)$ & $15.8(\mathrm{n}=3)$ \\
\hline \multicolumn{6}{|l|}{ Education Attainment (\%) } \\
\hline Primary or below & - & $3.3(n=3)$ & $0.0(n=0)$ & $0.0(n=0)$ & $15.8(\mathrm{n}=3)$ \\
\hline Secondary Level & - & $41.1(\mathrm{n}=37)$ & $27.0(\mathrm{n}=10)$ & $38.2(\mathrm{n}=13)$ & $73.7(\mathrm{n}=14)$ \\
\hline $\begin{array}{l}\text { Third Level } \\
\text { College/Institution }\end{array}$ & - & $43.3(n=39)$ & $56.8(\mathrm{n}=21)$ & $50.0(\mathrm{n}=17)$ & $5.3(\mathrm{n}=1)$ \\
\hline Postgraduate degree & - & $4.4(\mathrm{n}=4)$ & $8.1(n=3)$ & $2.9(\mathrm{n}=1)$ & $0.0(\mathrm{n}=0)$ \\
\hline Apprenticeships & - & $6.7(n=6)$ & $5.4(\mathrm{n}=2)$ & $8.8(n=3)$ & $5.3(\mathrm{n}=1)$ \\
\hline $\begin{array}{l}\text { Did not undertake formal } \\
\text { study }\end{array}$ & - & $1.1(\mathrm{n}=1)$ & $2.7(\mathrm{n}=1)$ & $0.0(\mathrm{n}=0)$ & $0.0(\mathrm{n}=0)$ \\
\hline
\end{tabular}

${ }^{a}$ Estimated, based on data sourced from [23]. ${ }^{b}$ Estimated, based on data sourced from [24]. Note that some respondents declined to provide details on livestock figures.

\section{Results}

\subsection{Demographical Characteristics and Rate of Adoption}

Table 1 provides a comparison between the respondent's characteristics and the national average in terms of personal attributes and the farming enterprise operation. When the respondents were asked, "Would you consider installing an anaerobic digestion plant on your farm in the next five years?" of the 91 participants, $40.7 \%(n=37)$ responded "yes", followed by $37.4 \%(n=34)$ that responded "maybe", and $22.0 \%(n=20)$ expressed no interest. For ease of analysis, in interpreting the results, three groups were created, which were "Likely Adopters" ("yes" respondents), "Possible Adopters" ("maybe" respondents), and "Non-Adopters" ("no" respondents).

Differences in contextual characteristics between the respondents in terms of adoption preference can be seen in Table 1. It was found that the mean total herd size of the "Likely Adopters" (125.1 animals) was generally greater than the "Non-Adopters" (76.1 animals). Of the farming types surveyed, dairy farmers were the most probable to be Likely Adopters $(40.5 \%)$, followed by mixed cattle farmers $(37.8 \%)$, and beef farmers expressing the least interest (21.6\%). This was anticipated as dairy and mixed cattle farmers would typically need to deal with larger quantities of wastes emanating from their processes, unlike beef farmers (where the cattle may graze for longer periods). The average farm size was 
larger than the national average (43.2 ha) at 62.3 ha (7 ha-243 ha) [24]. A chi-squared test for association was used to test respondent's attributes for statistically significant differentiators for being a "Likely Adopter" of AD. Of the variables tested, the level of educational attainment yielded a statistically significant result $(p=0.001)$.

In addition to examining the farmers' characteristics and their farming operations, the study also investigated the respondents' previous experiences with renewable energy (RE) technologies (if any) and used that as a potential indicator for future AD adoption. This is especially relevant since there is little information currently available to date on the motivations and uptake of RE technologies within the Irish agriculture context. Figure 2 presents the uptake rates of various RE technologies amongst the participants. Of the 91 participants surveyed, the existing adoption of RE technologies proved generally high $(17.6 \%)$ in comparison to other countries (in Europe) $[25,26]$. It emerged that solar panels were the most popular technology with an uptake rate at $14.3 \%$ of the total surveyed. With the exception of solar panels, poor uptake rates were reported for all other RE technologies. Issues cited include complications connecting to the national grid, insufficient government grant support, difficulties securing an electricity tariff, and a lack of awareness [12].

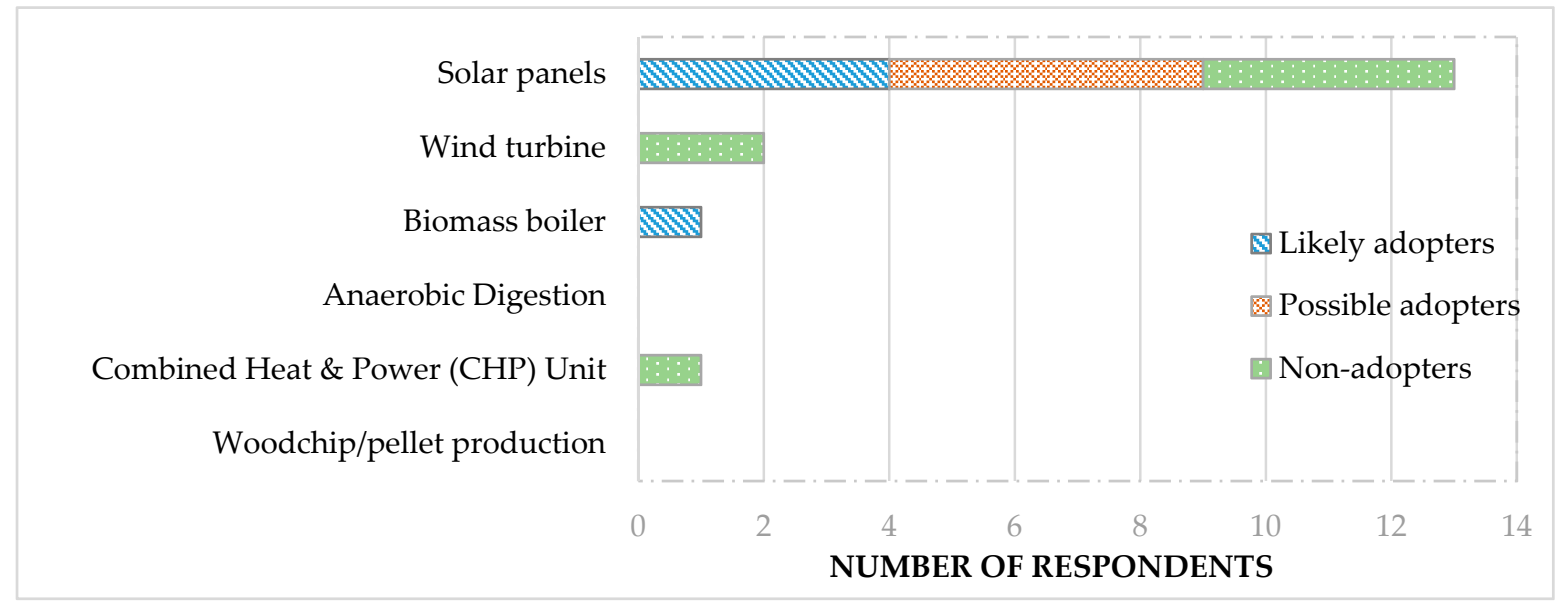

Figure 2. Farmer's previous implementation of renewable technologies.

Interestingly, of the farmers that had already implemented RE technologies on their farms, these mainly fell under those that were categorised as "Non-Adopters" (37.5\%) rather than "Likely Adopters" (31.3\%) and of "Possible Adopters" (31.3\%) of AD. However, the sample size which this conclusion is based on is relatively small $(n=16)$ with one respondent having installed two RE technologies. Moreover, respondents that indicated that they had implemented RE technologies, were then asked to disclose the motivating factor from several possible options. Of the factors listed, the following were indicated as contributors: to reduce farm business costs $(45 \%)$; to reduce greenhouse gas emissions $(20 \%)$; to add another source of revenue (15\%); to exploit government grants $(15 \%)$; and other motivations (5\%). Respondents were also given the opportunity to write-in other motivating factors, where the generation of renewable energy was listed. These results align with previous research conducted on farmers in the United Kingdom [26], where an uptake rate of $14 \%$ was observed, with solar panels also being the dominant RE technology implemented.

\subsection{Motivations to Implement the Technology}

Farmers were asked to rate the importance of several benefits that could be gained through the implementation of AD on their farming enterprise using Likert-scale from 1 (indicating that it was very important) to 4 (indicating it was unimportant). Table 2 summarises the responses received, where the mean and standard deviation are presented. Of the benefits presented to participants, factors relating to the plant's economics proved to 
be the most important. Interestingly, environmental benefits were also deemed important, but to a lesser extent. While "Likely Adopters", "Possible Adopters", and "Non-Adopters" differed in the level of importance given to items, there was a general agreement on the order of selection.

Table 2. Summary of survey responses to Likert-scale questions on the importance of various AD benefits.

\begin{tabular}{cccccc}
\hline Category & All Responses & Likely Adopters & Possible Adopters & Non-Adopters & ${ }^{\mathbf{a}} \boldsymbol{p}$-Value \\
\hline $\begin{array}{c}\text { To improve farm profitability } \\
\text { To reduce greenhouse gas }\end{array}$ & $1.49 \pm 0.69$ & $1.34 \pm 0.55$ & $1.48 \pm 068$ & $1.76 \pm 0.90$ & 0.0628 \\
$\quad \begin{array}{c}\text { emissions } \\
\text { To add another revenue }\end{array}$ & $1.92 \pm 0.91$ & $1.82 \pm 0.85$ & $1.93 \pm 0.81$ & $2.17 \pm 1.27$ & 0.3028 \\
$\quad$ stream & $1.57 \pm 0.64$ & $1.48 \pm 0.57$ & $1.57 \pm 0.63$ & $1.82 \pm 0.87$ & 0.1626 \\
$\quad \begin{array}{l}\text { To reduce farm pollution } \\
\text { To reduce farm business costs }\end{array}$ & $1.60 \pm 0.62$ & $1.69 \pm 0.59$ & $1.82 \pm 0.39$ & $2.09 \pm 1.04$ & 0.0959 \\
\hline
\end{tabular}

${ }^{\text {a }} p$-value results for $t$-test comparisons between Non-adopters and other adopter types.

The respondents were also asked their opinion on several potential obstacles that could prevent them from implementing AD on their farming enterprise. Participants were asked to rate their agreement on several statements using a Likert-scale from 1 (indicated that they strongly agree) to 5 (indicating they strongly disagreed). A summary of the responses provided by the participants is shown in Table 3. Of the options presented, the largest obstacles for both "Likely Adopters" and "Possible Adopters" was that there was not enough information about the technology, while "Non-Adopters" deemed the potentially high investment cost the largest barrier. These findings concur with previous studies conducted internationally [27-30]. In comparison, the least likely obstacle to AD adoption for adopter types was that the individual's rental agreement would not allow it. A likely contributing factor to this is the large portion of respondents who reported to wholly own (> 75\% of farmland) their farmland at 73.6\%. "Likely Adopters" and "Possible Adopters" generally agreed on the order of selection, while differing in the level of importance given to items. In addition, to gain an increased understanding, respondents were also given the opportunity to write-in other perceived obstacles to AD adoption. The responses received commented on the low electricity feed-in tariff (FIT) currently available, the high financial cost of gaining a grid connection, and the time necessary to monitor and operate the plant.

Table 3. Summary of survey responses to Likert-scale questions on the importance of potential AD obstacles.

\begin{tabular}{cccccc}
\hline Category & All Responses & Likely Adopters & Possible Adopters & Non-Adopters & a $p$-Value \\
\hline $\begin{array}{c}\text { I do not have enough information } \\
\text { Investment costs are too high }\end{array}$ & $1.75 \pm 0.90$ & $1.78 \pm 1.01$ & $1.42 \pm 0.5$ & $2.5 \pm 1.00$ & 0.0012 \\
$\begin{array}{c}\text { It would be too difficult to operate } \\
\text { The financial returns seem } \\
\text { uncertain }\end{array}$ & $3.05 \pm 0.83$ & $1.84 \pm 0.85$ & $1.97 \pm 0.87$ & $1.86 \pm 0.77$ & 0.8581 \\
$\quad 2.19 \pm 0.91$ & $2.17 \pm 0.87$ & $2.35 \pm 0.89$ & $1.93 \pm 1.00$ & 0.2376 \\
$\begin{array}{c}\text { I do not believe the technology has } \\
\text { been proven }\end{array}$ & $3.22 \pm 0.98$ & $3.14 \pm 1.19$ & $3.44 \pm 0.82$ & $2.91 \pm 0.54$ & 0.2567 \\
$\begin{array}{c}\text { My rental agreement would not } \\
\text { allow it }\end{array}$ & $3.4 \pm 0.90$ & $3.33 \pm 0.76$ & $3.5 \pm 0.95$ & $3.25 \pm 1.16$ & 0.6230 \\
$\quad \begin{array}{c}\text { It would be difficult to gain } \\
\text { planning permission }\end{array}$ & $2.71 \pm 0.96$ & $2.77 \pm 1.03$ & $2.52 \pm 1.01$ & $3.00 \pm 0.6$ & 0.2477 \\
\hline
\end{tabular}

a $p$-value results for $t$-test comparisons between Non-adopters and other adopter types.

\subsection{Preferred Operating Conditions}

Much debate has taken place in the literature between the use of small-scale anaerobic digestion (SSAD) plants and the more centralised medium to large-scale co-operative AD plants. Co-operative plants generally consist of multiple feedstock suppliers feeding a 
centralised AD plant, while SSAD plants typically consist of a single supplier feeding and operating a plant of lesser capacity. While co-operative plants have the benefits of greater economies of scale and reduced financial risk, SSAD plants provide greater control over feedstock quality and minimise multiple stakeholder involvement. This study aimed to provide a greater understanding of Irish cattle farmers' potential preferred AD plant operating arrangements if they were to implement the technology. Figure 3 shows the respondents preferred plant ownership and operating structures if they were to implement the technology in their own farming enterprise. "Non-Adopter" respondents were not included in the results, as they were deemed irrelevant. The reasoning for their exclusion is that they were unlikely to potentially operate or part-take in an AD enterprise. Of the choices available, "self-owned and operated" was the preferred option (40.3\%), followed by "self-owned and third party operated" $(29.9 \%)$, then "third-party owned and operated" $(16.4 \%)$, and finally "third-party owned and self-operated" (13.4\%).

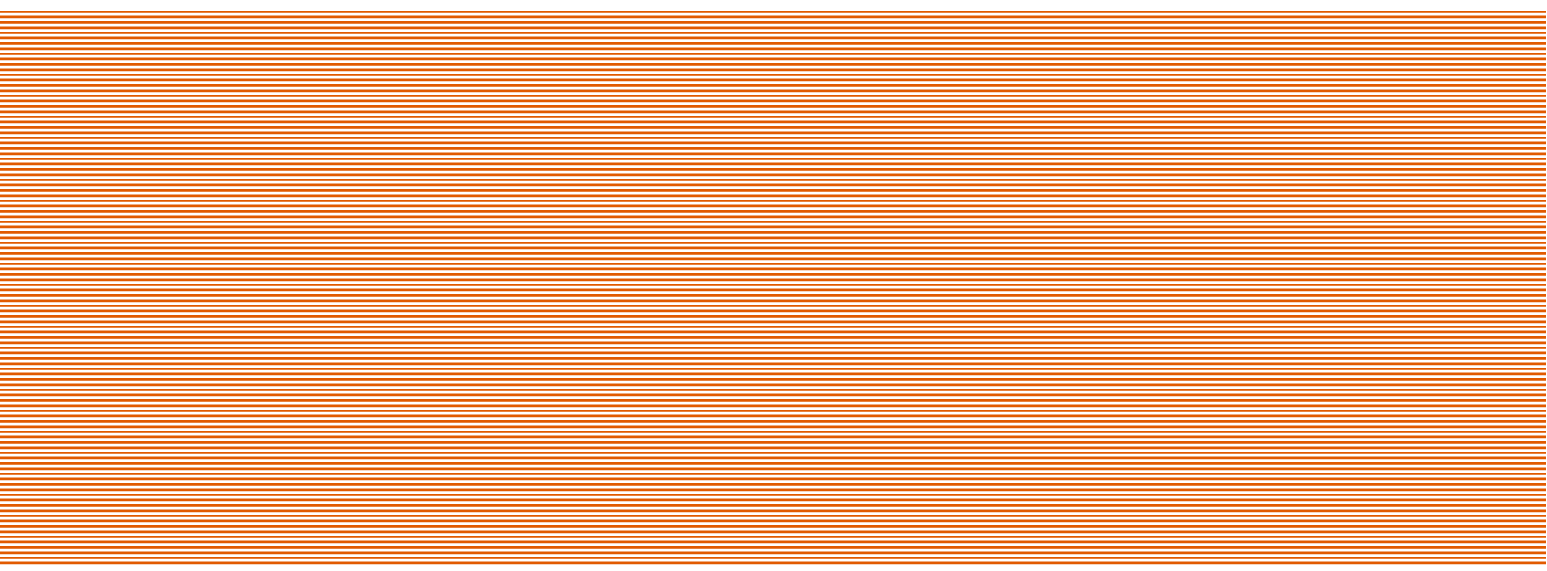

Figure 3. Survey responses preferred AD plant operating conditions.

Figure 4 provides a breakdown of the participants' responses when asked, "would you consider taking part in a co-operative scheme where 2 to 5 local farmers' feed slurry into an anaerobic digestion plant?". Similar to Figure 3, the responses from "Non-Adopter" were not included, as they were unlikely to operate or partake in an AD based enterprise. The results from the questioning were as follows, $58.0 \%$ responded "yes" $(n=40)$, followed by $33.3 \%(n=23)$ that responded "maybe", and 8.7\% $(n=6)$ answered "no". Of the examined respondents, two participants chose not to answer the question. The findings showed a large willingness of all categories to engage in AD based co-operative schemes.

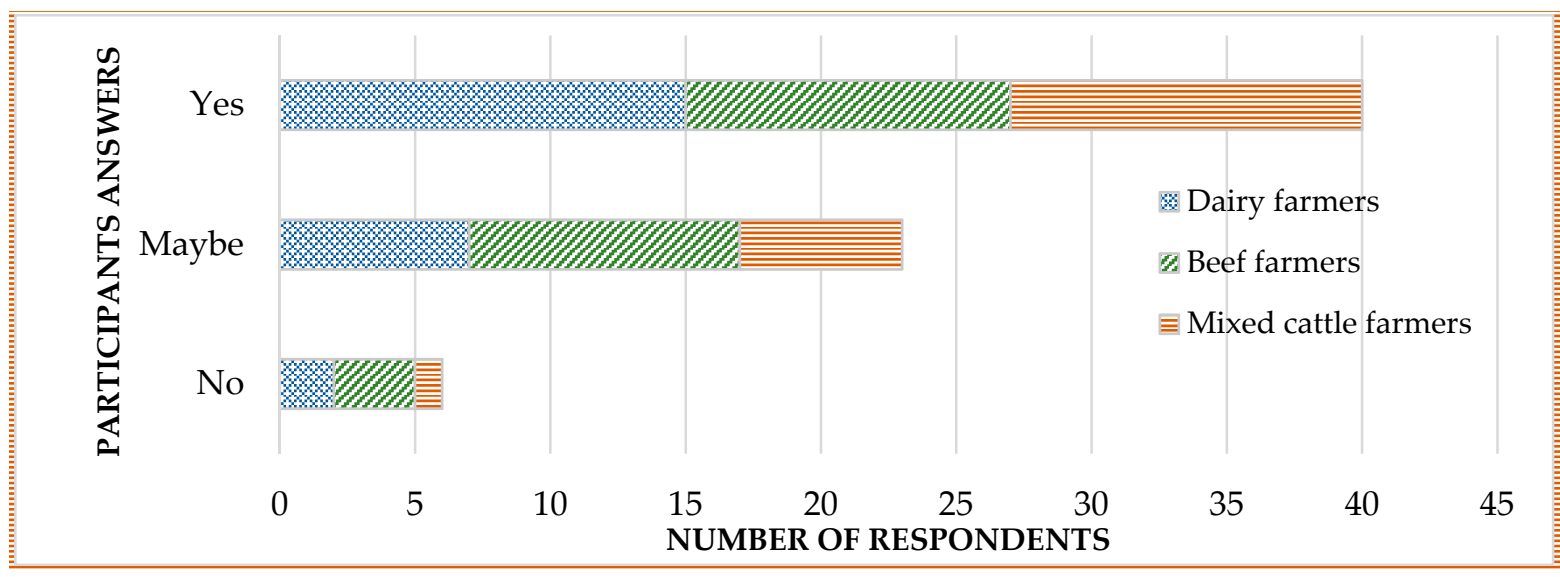

Figure 4. Survey responses willingness to partake in a co-operative scheme. 


\subsection{Broader Implications}

Table 4 provides a rough estimate of the potential technical and environmental implications if the "Likely Adopters" ( $\mathrm{n}=37$ ) identified in this study were to implement AD technology. These calculations are based solely on the collection of cattle manure and exclude the likely co-digestion of other feedstocks types such as energy crops, industry waste, or food waste. The inclusion of such feedstocks would likely increase the potential methane yield considerably. The total slurry available is based on an average yield of $52.2 \mathrm{~kg} \mathrm{day}^{-1}$ per head of cattle [31]. The collection of slurry for use as AD feedstock is based on animals being housed over the 16-week winter period (100\% collection) and left out to graze for the remainder of the year (20\% collection) [12,32]. Energy generation is based on the utilisation of combined heat and power (CHP) units, which are typically the most economically viable and widely used biogas utilisation technology available for agriculture based SSAD plants [17]. The potential electricity production is based on an estimated methane yield of $16.0 \pm 0.9 \mathrm{~m}^{3} \mathrm{CH}_{4} \mathrm{t}^{-1} \mathrm{FW}$, a methane energy density of 37.78 $\mathrm{MJ} / \mathrm{m}^{3}$, and a CHP electrical efficiency of $35 \%[33,34]$.

Table 4. Estimated feedstock availability and annual methane potential from "Likely Adopters" of AD.

\begin{tabular}{ccccc}
\hline & Dairy Farms & Beef Farms & Mixed Cattle Farms & Total Farms \\
\hline Number of livestock (animals) & 1684 & 401 & 2294 & 4379 \\
Fresh weight slurry yield ( $\left.\mathrm{t} \mathrm{year}^{-1}\right)$ & 14,276 & 3399 & 19,447 & 37,122 \\
Methane yield (m year $\left.^{-1}\right)$ & 228,412 & 54,390 & 311,150 & 593,952 \\
Potential electricity production via $\mathrm{CHP}(\mathrm{kWh}$ & 838,969 & 199,778 & $1,142,872$ & $2,181,619$ \\
year $^{-1}$ ) & 307.90 & 73.32 & 419.43 & 800.65 \\
$\mathrm{CO}_{2}$ savings $\left(\mathrm{t} \mathrm{CO}_{2}\right.$-eq. year $\left.^{-1}\right)$ & &
\end{tabular}

The potential environmental benefits are calculated based on all electricity produced being exported to the national grid with this displaced energy on average producing $0.367 \mathrm{t} \mathrm{CO}_{2} \mathrm{MWh}^{-1}$ [35]. Table 4 shows that significant energy generation and GHG emission savings are achievable from the Irish cattle industry. It is worth noting that the $\mathrm{CO}_{2}$ savings presented are likely to be an underestimate, as it excludes the use of the thermal (heat) energy generated and the release of methane to the atmosphere during storage and land application. The $\mathrm{CO}_{2}$ savings presented ( $800.65 \mathrm{tCO}_{2}$-eq. $\left.\mathrm{yr}^{1}\right)$, is equivalent to the displacement of 300,538 L of diesel annually or taking 238.71 cars off the road, assuming diesel consumption is $1259 \mathrm{~L}$ year $^{-1}$ and emissions of $2.67 \mathrm{~kg} \mathrm{CO}_{2}$ litre $^{-1}$ [36]. Over the life span of the $\mathrm{AD}$ plants (20 years), the $\mathrm{CO}_{2}$ reduction possible from the total farms was calculated to be $16,013+\mathrm{CO}_{2}$-eq [37-39].

\section{Discussion}

This study attempts to understand the motivations and opinions of Irish farmers in regard to the uptake and operation of farm-scale AD through a detailed analysis of a qualitative questionnaire. Although the research findings do not represent the views of the entire agricultural community, they do provide meaningful insights for the development of an Irish bioenergy industry. The study's analysis focuses on the economic and social dimensions apparent in the development and adoption of AD plants nationally. In this way, it complements existing literature on the topic, which has largely focused on the technical aspects. The study is one of the first academic contributions to identify farmer's opinions and readiness to adopt AD technologies within the Irish context.

This research has provided evidence that the willingness of Irish cattle farmers to implement or supply feedstock to AD plants to be relatively high and in line with earlier studies carried out in other European countries $[18,19]$. The demographical characteristics of "Likely Adopters" supported findings from previous studies, confirming age and educational attainment to be significant factors in respondents' willingness to engage with RE enterprises [18,40-42]. 
Of the farming types examined, the results showed dairy and mixed cattle farmers to be most likely to implement AD plants (40.5\%), with the least interest being expressed by beef farmers $(21.6 \%)$. It is likely that differences in profitability between these farming types may be a contributing factor as larger (more profitable) agriculture enterprises have been reported to be more inclined to introduce new technologies and equipment [18]. This subsequently influences the farming types examined, as dairy and mixed cattle farms generally exhibit higher net margins in Ireland [43]. In addition, respondents exhibited a high level of confidence in their ability to operate a biogas plant after sufficient training. These preferred operating and ownership structures could be invaluable to inform Irelands gas networks strategy, where Gas Networks Ireland (semi-state body) has set a goal for the national gas network to be net-zero carbon by 2050 [44].

Perceived outcomes (benefits and obstacles) proved to correlate highly with the respondent's willingness to implement AD technology. The findings from the Likert-scale questioning shown in Table 2, found that the main factors that motivated adoption was first to improve farm profitability $(1.49 \pm 0.69)$, followed closely by a wish to add another revenue source $(1.57 \pm 0.64)$. These results confirm findings obtained from earlier studies, where it was hypothesised that farmers/feedstock suppliers would be motivated to engage with RE technologies if they were likely to contribute to the economic growth of the farming enterprise [26,45-47]. In addition to economic benefits, environmental advantages were also identified as motivating factors. This was anticipated, as farmers are increasingly facing regulatory and societal pressure to implement strategies and technologies to mitigate GHG emissions and to reduce their dependence on fossil fuels $[3,48,49]$.

After reflecting on the obstacles identified in the analysis, the authors do not present a hierarchy of barriers but rather a set of issues that must be addressed holistically. While adoption was driven primarily by economic factors, the single largest barrier identified was a lack of awareness and inadequate information regarding the technology. A key strategy to overcome this difficulty is the use of early adopters or local champions to increase awareness and to promote the technologies positive attributes, therefore, demonstrating the positive contribution possible to the performance of the farming enterprise as well as acting as a model for other farmers to duplicate [26,50]. Similar initiatives enacted by policymakers have proved effective in increasing awareness and adoption rates in other countries (e.g., United Kingdom, Belgium, and the Netherlands,) [26,51-53]. A recent Irish initiative following this methodology is the EIP Small Biogas Demonstration Project, which aims to promote SSAD through informative workshops, feasibility studies, and the provision of capital grants for the construction of three biogas plants [54]. When completed, it is envisioned that these plants will act as demonstration projects, which will potentially address or lessen the obstacles highlighted by respondents.

Other barriers identified include the potentially high investment costs and uncertainty in regard to the technology's financial returns. Stakeholder concerns regarding the economics of RE enterprises have been commonly reported in the existing literature $[28,55]$. In an effort to overcome such difficulties, many governments have introduced incentives (e.g., electrical feed-in tariffs, capital grants, and heat tariffs), which can prove vital to the financial viability of RE projects, especially for early adopters [56,57]. In an effort to increase the generation of energy from RE sources, the Irish government have recently introduced an initiative named the Support Scheme for Renewable Heat [58]. The scheme is designed to increase the energy generated from RE sources, where it provides two tariffs to biogas plant operators of $2.95 \mathrm{cEUR} \mathrm{kWh}^{-1}$ (plants generating less than $1000 \mathrm{MWh}^{-1 e a r^{-1}}$ ) and $0.50 \mathrm{cEUR} \mathrm{kWh}^{-1}$ (plants generating 1000 to $2400 \mathrm{MWh}$ year $^{-1}$ ) for heat generated that displaces conventional fossil fuel alternatives [58].

Although the study has generated considerable new insights, some potential limitations need to be addressed. It should be noted that the sample size had a larger herd and farm size then the national average. The authors believe that a potential contributing factor may have been the audience and platforms used for the collection of data, favouring a greater receipt of responses from larger sized (than national average) farms. The reasoning 
being that such dissemination platforms mainly attract farmers actively engaged in farming full-time, which are more likely to have larger farms. This is opposed to the overall farming sector landscape captured in the national registry, which also includes smaller farm holdings, managed by part-time farmers. Other potential contributing factors include the respondents' biases to report favourable figures, and the relatively small sample size captured by the study. For future research, we suggest that a more in-depth analysis is needed of Irish farmers willingness to adopt AD technologies based on the technical, environmental, and economic conditions specific to their own farming enterprise. Moreover, further research is needed to how greater value creation and environmental benefits can be achieved through plant analysis and AD-based biorefinery platforms, subsequently accelerating the development of a circular economy [16,59-62].

Looking forward, it is anticipated as the consequences of climate change become increasingly apparent; there will be growing social and political pressure to mitigate the negative environmental impacts of all industries. Of the RE technologies available, AD holds considerable potential for the generation of renewable energy and the reduction of GHG emissions, particularly in the agriculture sector. It is hoped that through the increased understanding provided, that the results will positively influence the development of the industry by guiding future initiatives in regard to farmers' preferences and concerns.

\section{Conclusions}

Farm-scale AD can play a considerable role in reducing the negative environmental impacts associated with small to medium-sized agriculture enterprises. In addition, to GHG reduction, plants afford other benefits such as on-site energy generation, the provision of a nutrient-rich fertiliser from the digester effluents, and the reduction of odour and pathogen loads. Therefore, to provide a greater understanding of the technology's potential within the Irish context, this study investigated cattle farmers' perception and willingness to adopt the technology. The results revealed that $41 \%$ of participants responded "yes" when asked would they consider implementing AD on their farming enterprise within the next five years. These "Likely Adopters" were generally characterised by having a higher level of educational attainment in comparison to other respondents. High investment costs and a lack of information regarding the technology were found to be the leading barriers to implementation, while its potential to improving farm profitability was the greatest perceived benefit. Of the "Likely Adopters" and "Possible Adopters", 58\% were interested in partaking in a co-operative scheme where two to five farmers feed a centralised $\mathrm{AD}$ plant, while a "Self-owned and operated" business model was the preferred business model (40.3\%). The study estimates that if all "Likely Adopters" identified, implemented the technology, a $\mathrm{CO}_{2}$ reduction of $800.65 \mathrm{t} \mathrm{CO}_{2}$-eq. year ${ }^{-1}$ and electricity production of $2182 \mathrm{MWh}$ year $^{-1}$ was potentially achievable. The broader implications of this work highlight the potential willingness of farmers to implement AD or to supply feedstock to a centralised plant. Going forward, it is hoped that the insights developed in this study will guide researchers, policymakers and $\mathrm{AD}$ operators in furthering the development of an indigenous bioenergy industry.

Supplementary Materials: The following are available online at https://www.mdpi.com/2076-329 8/8/2/8/s1, Survey questions.

Author Contributions: Conceptualisation, S.O., E.E., and J.B.; validation, S.O., E.E., S.C.P., N.P., G.A.L. and J.B.; writing — original draft preparation, S.O.; writing—review and editing, S.O., E.E., S.C.P., N.P., G.A.L. and J.B.; supervision, E.E., S.C.P. and J.B. All authors have read and agreed to the published version of the manuscript.

Funding: The research leading to these results has received funding from the European Union's INTERREG VA Programme, managed by the Special EU Programmes Body (SEUPB), with match funding provided by the Department for the Economy (Northern Ireland) and Department of Enterprise, Trade and Employment (Republic of Ireland), grant number IVA5033. The views and 
opinions expressed in this article do not necessarily reflect those of the European Commission or the Special EU Programmes Body (SEUPB).

Informed Consent Statement: Informed consent was obtained from all subjects involved in the study.

Data Availability Statement: The data presented in this study are available on request from the corresponding author.

Conflicts of Interest: The authors declare no conflict of interest. The funders had no role in the design of the study; in the collection, analyses, or interpretation of data; in the writing of the manuscript, or in the decision to publish the results.

\section{References}

1. Hopfner-Sixt, K.; Amon, T. Monitoring of agricultural biogas plants in Austria-Mixing technology and specific values of essential process parameters (2007). Bioresour. Technol. 2009, 100, 4931-4944.

2. European Commission Communication. "20 20 by 2020_Europe's Climate Change Opportunity"; COM: Brussels, Belgium, 2008.

3. European Commission Communication. "A Policy Framezork for Climate and Energy in the Period from 2020 to 2030"; COM: Brussels, Belgium, 2014.

4. Ireland's Greenhouse Gas Emissions Projections 2019-2040; Environmental Protection Agency: Wexford, Ireland, 2020.

5. Ireland's Final Greenhouse Gas Emissions 1990-2018; Environmental Protection Agency: Wexford, Ireland, 2020.

6. Central Statistics Office. Crops and Livestock Survey 2019 June Final Results. Available online: https://www.cso.ie/en/ releasesandpublications/er/clsjf/cropsandlivestocksurveyjunefinal2019/\#: \{\}:text=Thefinalresu (accessed on 9 August 2020).

7. Enterprise Ireland Dairy and Ingredients. Available online: https://www.enterprise-ireland.com/en/start-a-business-inireland/food-investment-from-outside-ireland/key-sectors/dairy-and-ingredients/dairy-and-ingredients.html (accessed on 13 May 2018).

8. Shalloo, L.; Connor, D.O.; Cele, L.; Thorne, F.; Egan, M. An Analysis of the Irish Dairy Sector Post Quota; Teagasc: Cork, Ireland, 2020.

9. Štambaský, J. The potential Size of the Anaerobic Digestion Industry in Ireland by the Year 2030; NovaEnergo: Prague, Czech Republic, 2016.

10. Irish Bioenergy Association. Irish Bioenergy 2017-Biomass, Biogas and Biofuels. Available online: https://www.irbea.org/ bioenergy-installations-map-ireland/ (accessed on 16 September 2020).

11. Ireland's Final Greenhouse Gas Emissions 1990-2017; Environmental Protection Agency: Wexford, Ireland, 2019.

12. O'Connor, S.; Ehimen, E.; Pillai, S.C.; Lyons, G.; Bartlett, J. Economic and Environmental Analysis of Small-Scale Anaerobic Digestion Plants on Irish Dairy Farms. Energies 2020, 13, 637. [CrossRef]

13. Auer, A.; Vande Burgt, N.H.; Abram, F.; Barry, G.; Fenton, O.; Markey, B.K.; Nolan, S.; Richards, K.; Bolton, D.; De Waal, T.; et al. Agricultural anaerobic digestion power plants in Ireland and Germany: Policy and practice. J. Sci. Food Agric. 2017, 97, 719-723. [CrossRef] [PubMed]

14. Tedesco, S.; Stokes, J. Valorisation to biogas of macroalgal waste streams: A circular approach to bioproducts and bioenergy in Ireland. Chem. Pap. 2017, 71, 721-728. [CrossRef]

15. Beausang, C.; McDonnell, K.; Murphy, F. Anaerobic digestion of poultry litter-A consequential life cycle assessment. Sci. Total Environ. 2020, 735. [CrossRef]

16. Ehimen, E.; O'Connor, S. Decentralised Anaerobic Digestion Systems as Basis for Future Biorefinery Platforms. In Biorefineries: A Step Towards Renewable and Clean Energy; Verma, P., Ed.; Springer: Singapore, 2021; pp. 561-580, ISBN 978-981-15-9593-6.

17. O'Connor, S.; Ehimen, E.; Pillai, S.C.; Black, A.; Bartlett, J. Biogas production from small-scale anaerobic digestion plants on European farms. Renew. Sustain. Energy Rev. 2021. [CrossRef]

18. Tranter, R.B.; Swinbank, A.; Jones, P.J.; Banks, C.J.; Salter, A.M. Assessing the potential for the uptake of on-farm anaerobic digestion for energy production in England. Energy Policy 2011, 39, 2424-2430. [CrossRef]

19. Shimahata, A.; Farghali, M.; Fujii, M. Factors Influencing the Willingness of Dairy Farmers to Adopt Biogas Plants: A Case Study in Hokkaido, Japan. Sustainability 2020, 12, 7809. [CrossRef]

20. Wahyudi, J. The Determinant Factors of Biogas Technology Adoption in Cattle Farming: Evidences from Pati. J. Renew. Energy Dev. 2017, 6, 235-240. [CrossRef]

21. Kabir, H.; Yegbemey, R.N.; Bauer, S. Factors determinant of biogas adoption in Bangladesh. Renew. Sustain. Energy Rev. 2013, 28, 881-889. [CrossRef]

22. Central Statistics Office Ireland. Livestock Survey December 2019. Available online: http:/ /www.cso.ie/en/releasesandpublications/ er/lsd/livestocksurveydecember2019/ (accessed on 21 February 2020).

23. Central Statistics Office Ireland Farm Structure Survey 2016. Available online: https://www.cso.ie/en/releasesandpublications/ ep/p-fss/farmstructuresurvey2016/ (accessed on 1 November 2020).

24. Donnellan, T.; Moran, B.; Lennon, J.; Dillon, E. Teagasc National Farm Survey 2019 Results; Teagsc: Carlow, Ireland, 2020. 
25. Soland, M.; Steimer, N.; Walter, G. Local acceptance of existing biogas plants in Switzerland. Energy Policy 2013, 61, 802-810. [CrossRef]

26. Mbzibain, A.; Hocking, T.J.; Tate, G.; Ali, S. Renewable enterprises on UK farms: Assessing levels of uptake, motivations and constraints to widespread adoption. Biomass Bioenergy 2013, 49, 28-37. [CrossRef]

27. Zoellner, J.; Schweizer-Ries, P.; Wemheuer, C. Public acceptance of renewable energies: Results from case studies in Germany Energy Policy 2008, 36, 4136-4141. [CrossRef]

28. Ackrill, R.; Abdo, H. On-farm anaerobic digestion uptake barriers and required incentives: A case study of the UK East Midlands region. J. Clean. Prod. 2020, 264, 121727. [CrossRef]

29. Upreti, B.R. Conflict over biomass energy development in the United Kingdom: Some observations and lessons from England and Wales. Energy Policy 2004, 32, 785-800. [CrossRef]

30. Slade, R.; Panoutsou, C.; Bauen, A. Reconciling bio-energy policy and delivery in the UK: Will UK policy initiatives lead to increased deployment? Biomass Bioenergy 2009, 33, 679-688. [CrossRef]

31. Midwest Plan Service Livestock Waste Facilities Handbook, 2nd ed.; Midwest Plan Service: Ames, IA, USA, $1985 ;$ ISBN 0893730637.

32. Hennessy, T.; Moran, B.; Thorne, F.; French, P.; McNamara, J.; Murphy, P.; Keena, C.; Hyde, T.; Gibson, M.; O’Dwyer, J.; et al. Teagasc Dairy Manual. Available online: https:/ / www.teagasc.ie/publications/2016/teagasc-dairy-manual.php (accessed on 7 October 2020).

33. Lantz, M. The economic performance of combined heat and power from biogas produced from manure in Sweden-A comparison of different CHP technologies. Appl. Energy 2012, 98, 502-511. [CrossRef]

34. Wall, D.M.; O'Kiely, P.; Murphy, J.D. The potential for biomethane from grass and slurry to satisfy renewable energy targets. Bioresour. Technol. 2013, 149, 425-431. [CrossRef]

35. Commission for Regulation of Utilities. Fuel Mix Disclosure 2016. Available online: https://www.cru.ie/wp-content/uploads/ 2017/10/CRU17288-CRU-Fuel-Mix-Disclosure-and-CO2-Emission-2016-version-28-September-2017-FINAL-PDF.pdf (accessed on 26 June 2020).

36. Central Statistics Office. Fuel Consumption by Sector, Fuel Type and Year. Available online: https://statbank.cso.ie/px/ pxeirestat/Statire/SelectVarVal/Define.asp?maintable=SEI06\&PLanguage=0 (accessed on 22 May 2020).

37. Bishop, C.P.; Shumway, C.R. The Economics of Dairy Anaerobic Digestion with Coproduct Marketing. Rev. Agric. Econ. 2009, 31, 394-41016. [CrossRef]

38. Metcalf \& Eddy. Wastewater Engineering: Treatment and Resource Recovery, 5th ed.; McGraw-Hill Higher Education: New York, NY, USA, 2014; ISBN 9780073401188.

39. U.S. Army Crops of Engineers (USACE). Federal Discount Rate for Fiscal Year 2012: Economic Guidance Memorandum 12-01; USACE: Washington, DC, USA, 2011.

40. Jensen, K.; Clark, C.D.; Ellis, P.; English, B.; Menard, J.; Walsh, M.; de la Torre Ugarte, D. Farmer willingness to grow switchgrass for energy production. Biomass Bioenergy 2007, 31, 773-781. [CrossRef]

41. Clancy, D.; Breen, J.; Moran, B.; Thorne, F.; Wallace, M. Examining the socio-economic factors affecting willingness to adopt bioenergy crops. J. Int. Farm Manag. 2011, 5, 1-16.

42. Paulrud, S.; Laitila, T. Farmers' attitudes about growing energy crops: A choice experiment approach. Biomass Bioenergy 2010, 34, 1770-1779. [CrossRef]

43. Dillon, E.; Moran, B.; Donnellan, T. Teagasc National Farm Survey 2016 Results. Available online: https://www.teagasc.ie/ media/website/publications /2017/NFS-2016-Final-Report.pdf (accessed on 11 May 2020).

44. Gas Network Ireland. Vision 2050—A net zero carbon gas network for Ireland. Available online: https://www.gasnetworks.ie/ vision-2050/future-of-gas/GNI_Vision_2050_Report_Final.pdf (accessed on 21 October 2020).

45. Plieninger, T.; Bens, O.; Hüttl, R.F. Perspectives of Bioenergy for Agriculture and Rural Areas. Outlook Agric. 2006, 35, $123-127$. [CrossRef]

46. Sattler, C.; Nagel, U.J. Factors affecting farmers' acceptance of conservation measures-A case study from north-eastern Germany. Land Use Policy 2010, 27, 70-77. [CrossRef]

47. Adams, P.W.; Hammond, G.P.; McManus, M.C.; Mezzullo, W.G. Barriers to and drivers for UK bioenergy development. Renew. Sustain. Energy Rev. 2011, 15, 1217-1227. [CrossRef]

48. European Commission. Decision No 406/2009/EC of the European Parliament and of the Council of 23 April 2009 on the Effort of member States to Reduce Their Greenhouse Gas Emissions to Meet the Community's Greenhouse Gas Emission Reduction Commitments up to 2020. Off. J. Eur. Union 2009.

49. Report from the Commission to the Council and the European Parliament on the Implementation of Council Directive 91/676/EEC of 12 December 1991 Concerning the Protection of Waters against Pollution Caused by Nitrates from Agricultural Sources Based on Member State Reports for the Period 2008-2011; European Commission: Brussels, Belgium, 2013.

50. Upreti, B.R.; Van Der Horst, D. National renewable energy policy and local opposition in the UK: The failed development of a biomass electricity plant. Biomass Bioenergy 2004, 26, 61-69. [CrossRef]

51. De Dobbelaere, A.; De Keulenaere, B.; De Mey, J.; Lebuf, V.; Meers, E.; Ryckaert, B.; Schollier, C.; Van Driessche, J. Small scale anaerobic digestion: Case studies in Western Europe. Enerpedia 2015. [CrossRef]

52. AFBI Northern Ireland: Benefits and Supply Chain of AD Systems; Agri Food and Bioscience Institute: Belfast, Ireland, 2013. 
53. Bijnagte, J.W. Public Final Report BioEnergy Farm II; BioEnergy Farm II publication, Cornelissen Consulting Services B.V.: Deventer, The Netherlands, 2017.

54. Department of Agriculture Fisheries and the Marine. EIP-AGRI: Ireland's Operational Groups 2019. Available online: https: / / www.agriculture.gov.ie/media/migration/farmingschemesandpayments / europeaninnovationpartnership/EIPAGRIOperationalGroupBooklet2019proof2.pdf (accessed on 21 October 2020).

55. Ricardo Energy \& Environment Ltd. Assessment of Cost and Benefits of Biogas and Biomethane in Ireland. Available online: https: / / www.seai.ie/resources/publications / Assessment-of-Cost-and-Benefits-of-Biogas-and-Biomethane-in-Ireland.pdf (accessed on 11 May 2020).

56. Lukehurst, C.; Bywater, A. Exploring the Viability of Small Scale Anaerobic Digesters in Livestock Farming; IEA Bioenergy: Birmingham, UK, 2015; ISBN 9781910154250.

57. Pablo-Romero, M.D.; Sánchez-Braza, A.; Salvador-Ponce, J.; Sánchez-Labrador, N. An overview of feed-in tariffs, premiums and tenders to promote electricity from biogas in the EU-28. Renew. Sustain. Energy Rev. 2017, 73, 1366-1379. [CrossRef]

58. Department of Communications Climate Action \& Environment Support Scheme for Renewable Heat-Scheme Overview. Available online: https:/ / www.seai.ie/publications/SSRH-Scheme-Details-.pdf (accessed on 27 March 2019).

59. Lijó, L.; González-García, S.; Bacenetti, J.; Negri, M.; Fiala, M.; Feijoo, G.; Moreira, M.T. Environmental assessment of farm-scaled anaerobic co-digestion for bioenergy production. Waste Manag. 2015, 41, 50-59. [CrossRef]

60. Bacenetti, J.; Fiala, M. Carbon Footprint of Electricity from Anaerobic Digestion Plants in Italy. Environ. Eng. Manag. J. 2015, 14, 1495-1502. [CrossRef]

61. Ingrao, C.; Bacenetti, J.; Adamczyk, J.; Ferrante, V.; Messineo, A.; Huisingh, D. Investigating energy and environmental issues of agro-biogas derived energy systems: A comprehensive review of Life Cycle Assessments. Renew. Energy 2019, 136, 296-307. [CrossRef]

62. Ingrao, C.; Faccilongo, N.; Di Gioia, L.; Messineo, A. Food waste recovery into energy in a circular economy perspective: A comprehensive review of aspects related to plant operation and environmental assessment. J. Clean. Prod. 2018, 184, 869-892. [CrossRef] 